\title{
Türkiye'de İş Kazaları ve Meslek Hastalıklarına Yönelik Hukuksal Düzenlemelerin Başlangıç Dönemi
}

\author{
Önder Deniz
}

Uşak Üniversitesi İletişim Fakültesi, Uşak.

\section{$\ddot{O} z$}

Sanayileşmenin olumlu sonuçlarının yanında sosyal açıdan olumsuz birtakım sonuçları da olmuştur. Çalışma ortamlarının sağlıksız olması ve birçok tehlikeleri barındırması, işçi kesimleri için en önemli sorunların başında gelmektedir. Üretim unsurlarmın en üst düzeyde kullanımı, iş̧̧i kesimine çok ağır bir şekilde yansımıştır. Tarihsel süreç içerisinde uzun bir süre işçiler, çalışma koşullarından dolayı, hastalandı, sakat kaldı veya hayatlarını kaybetti. Bu acımasız yapının durdurulmasına yönelik çalışmalar 19. yüzyılın ikinci yarısında başlamıştır. Başlarda çocuk işçilerin korunması üzerine yapılan çalışmalar, daha sonra genel işgücünü kapsayacak şekilde genişletildi. İnsan sağhlğ̆ üzerine yapılan araştırmalar geliştikçe, çalışma ortamlarındaki işçi sağhlğ ve güvenliğine yönelik çalışmalar da gelişmiştir. Çalışma koşullarından dolayı işçilerin karşılaşabilecekleri sağllk sorunları ve meslek hastalıklarının en aza indirilmesi için yapılanlar, çalışma hayatına yönelik sosyal politikaların temelini oluşturmaktadır. Türkiye'de buna yönelik çalışmalar, 19. yüzyılın ikinci yarısına karşılık gelmektedir. Madenlerdeki işçi sağlığı ve güvenliğini koruma amaçlı hukuksal düzenlemeler, ülkedeki iş săğl̆ğı ve güvenliği çalışmalarının başlangıcını oluşturur. Hukuksal düzenlemelerin başlangıç tarihi eski olsa da ileriki yıllarda devleti yönetenler, işçinin să̆hlğını ve güvenliğini koruyucu genel bir kanun yapma konusunda yetersiz kalmışlardır. Uzun süre işverenler, çalışma koşulların kendi menfaatine göre düzenlemiştir. Türkiye'de iş să̆lı̆̆ ve güvenliğgi ancak 20. yüzyllın ortalarında hukuksal bir yapıya kavuşmuştur, ayn zamanda Umumi Hıfzıssıhha Kanununda sonra da İş Kanununda işçi sağhığın koruyucu maddelere yer verilmiştir. Bu iki kanunun olumlu bir yapıya sahip olmalarına karşılık birçok işçi kanunun kapsamı dışında kalmıştır. Türkiye'de iş̧̧ileri koruyucu önlemler, başlangıç döneminde sınırlı düzeyde kalmıştır.

Anahtar Kelimeler: İş Hukuku, Çalışma Hayatı, İş Kazası, Meslek Hastalı̆̆

\section{Initial Term of the Legal Regulations for the Work Accidents and Occupational Diseases in Turkey}

\begin{abstract}
In addition to the positive results, there were some negative social consequences of industrialization. Unhealthy working conditions as well as many dangereous working environments are the most important problems for the workers. The utmost use of production elements was a heavy burden on workers' backs. For a long time in the historical process, workers became ill, disabled or lost their lives due to working conditions. In order to stop this brutal structure, the studies began in the second half of the 19th century. In addition to the early studies for the protection of child workers, there were later some expanded ones to cover the general workforce. As the researches on general human health evolved, the studies on workers' health and safety including working environments also developed. Minimizing the health problems and occupational diseases that workers may face due to working conditions is the basis of social policies for working life. For this, the studies in Turkey corresponds to the second half of the 19th century. Legal arrangements for the protection of workers' health and safety in the mines constitute the beginnings of occupational health and safety studies in Turkey. Even though the starting date of
\end{abstract}


the legal arrangements was old in Turkey, the politicians ruling the country in the following years were insufficient to make a general law protecting the health and safety of the workers. For a long time, employers arranged the working conditions according to their own interests. The occupational health and safety in Turkey became a legal structure in the middle of the 20th century. Later, the articles about workers' health were included in the Labor Act and then in the Preservation of Public Health Act. Despite the fact that these two acts had a positive approach, many workers still remained out of the scope of these laws. The protective measures taken for the safety of workers in Turkey, remained limited level as it was at the beginning period.

Keywords: Labor Law, Working Life, Work Accident, Occupational Disease

\section{GİRIŞ}

Sanayi Devrimi, iktisadi, siyasal ve toplumsal değişime neden olmuş ve yeni bir çağın doğmasına yol açmıştır ${ }^{1}$. Üretim unsurlarını elinde tutan burjuva, zenginleşmekle kalmayıp bağlı bulundukları ülkeleri siyasi olarak güçlendirmiştir². Ancak bu dönemde sayıları günden güne artan ve üretimin ana unsurunu oluşturan işçiler, sanayi devriminin yarattığı olumlu yapıdan fayda değil tam tersi zarar görmüşlerdir. İş kazaları ve meslek hastalıkları, işçiler için hayatın bir parçası haline gelmiştir. Fabrika sayısı arttıkça çalışma koşulları her yaştan bireyi olumsuz yönde etkilemiştir. 19. yüzyıla gelindiğinde fabrikalarda neredeyse her yaştan çocuk işçi vardı. Bu dönemde sürekli ve ucuz üretim için çocuk işçiler, tehlikeli tehlikesiz, gece gündüz demeden her işte çalıştırılmaktadır. Bu durum, sosyal hayatın bir aynası konumunda olan edebiyat alanında, özellikle de Charles Dickens'ın romanlarında çocuk kahramanlar olarak karşımıza çıkmaktadır³. Ayrıca kadın işçiler de çocuk işçiler gibi çalışma hayatında ezilenler arasında yer almıştır. Düşük ücretlerle tehlikeli işlerde çalıştırılan kadınlar, meslek hastalığı riskine en yatkın kesimdi. Aynı şekilde erkek işçiler de çocuk ve kadın işçiler gibi ağır şartlarda düşük ücretlerde çalışmaya mahkum bırakılmıştır ${ }^{5}$.

Bu bozuk yapıyı gören ve düzeltmek isteyen Saint Simon, Charles Found, Robert Owen gibi düşünürler, tamamen insancıl düşüncelerle çalışma hayatındaki olumsuzlukları ortadan kaldırmaya yönelik ilk bilimsel çalışmaları başlatmışlardır. Bu dönemde ayrıca yönetimi elinde tutanlar, günden güne zenginleşen burjuva ile temel haklardan mahrum bırakılmış işçi topluluğu, arasında bir çatışma ortamı olmasını engellemek için çalışmaları başlatmışlardır' ${ }^{6}$. İşçilerin çalışma koşullarına yönelik hukuksal düzenlemeler ile başlayan süreç, sosyal demokrasi olgusunu oluşturmuştur ${ }^{7}$

\footnotetext{
${ }^{1}$ Paul Kennedy, Büyük Güçlerin Yükseliş ve Çöküşleri, Çeviren: Birtane Karanakçı, Türkiye İş Bankası Yayınları, Ankara, 1994, s. 169,170.

2 E. J. Hobsbawn, Sanayi ve İmparatorluk, Çeviren: Abdullah Ersoy, Dost Yayınları, Ankara, 1998, s.13.

${ }^{3}$ Y.Z. Turan, R. Çolak, “Bildungsroman'a Tematik Bir Yaklaşım: David Copperfield ve Çalıkuşu”. Humanitas: Uluslararası Sosyal Bilimler Dergisi, Cilt.4, Say1.7,2016,s.s. 457-467.

${ }^{4}$ Murteza Aydemir, "İşçi Sağlı̆̆ı ve İş Güvenliğini Sağlama Açısından İşverenin Yükümlüğü", Kamu-İş İş Hukuku ve İktisat Dergisi, Cilt.3, Sayı.4, Temmuz, 1994, s.s.78-79.

${ }^{5}$ Cahit Talas, İçtimai İktisat Dersleri, Ankara Üniversitesi Siyasal Bilgiler Fakültesi Yayınları, Ankara, 1955, s.s. 8-15.

${ }^{6}$ A.g.e., s.24.

${ }^{7}$ Orhan Tuna, Nevzat Yalçıntaş, Sosyal Siyaset, Filiz Yayınları, İstanbul, 1988, s.11.
} 
İşçi, işveren ve devletin çalışma hayatında hukuksal düzenlemelerde taraf olması, sosyal adalet, sosyal devlet, sosyal haklar gibi yeni değerlerin oluşmasını da sağlamıştır. İngiliz iş adamı Robert Owen çocuk iş gücüne yönelik çalışmalarıyla çalışma hayatında işçinin lehine müdahalelerin başlangıcını temsil eder8. Demokrasinin gelişmesi ile birlikte kapsam genişletilmiş, özellikle iş kazaları ve meslek hastalıklarına yönelik daha bilimsel çalışmaların önü açılmıştır.

Osmanlı Devleti'nin kapalı iktisadi yapısı, ancak bu yüzyılın ortalarında sanayileşmiş ülkelerle yapılan ticaret anlaşmaları ile değişmeye başlamıştır. Zanaat ve tarım dışı iş gücü yüzyılın sonlarına doğru değişmiştir. Yabancı sermayenin ulaştırma ve hammadde üretimine yönelik çalışmaları, Osmanlı topraklarında fabrikaya dayalı üretimi başlatmıştır. Ayrıca bu dönemde devlet teşebbüsü ile de genelde askeri ihtiyaçlara yönelik fabrikalar açılmıştır.

Osmanlı Devleti'nin iktisadi hayatına yön verenler sanayileşmenin önemini anlamış ve fabrika türü işletmelerin sayısını artırmaya çalışmıştır9. 20. yüzyıla girildiğinde Osmanlı sanayi işletmelerindeki çalışma hayatının, karmaşık bir yapıda olduğu görülmektedir. Devlet işletmelerinde asker ve angarya işgücü çalışırken özel sektör işletmelerinde yerli ve yabancı işgücü istihdam edilmiştir. Bunun dışında işçiler arasında statü farkı olmuştur. Vasıflı işgücü "işçi” olarak adlandırılmakta ve genelde yabancı ülkeden gelen işçiler için kullanılmaktadır. Türk ve Müslüman işçiler ise çoğunlukla amele olarak adlandırılmıştır. ${ }^{10}$

Çalışma hayatındaki karmaşık yapı, sosyal politikaları doğrudan etkilemiştir. $\mathrm{Bu}$ alana yönelik sosyal politikalar bölgesel ve çok sınırlı düzeyde kalmıştır. Aynı zamanda iş kazaları ve meslek hastalıklarına yönelik çalışmalar, sadece devlet kontrolündeki madenler ile sınırlı kalmıştır. Fabrikaya dayalı üretimin getirdiği meslek hastalıkları ve iş kazaları, 20. yüzyılın başlarında Osmanlı Devleti'nde önemsenecek konular arasında yer almamıştır. İş kazaları ve meslek hastalıklarına yönelik Türkiye'deki çalışmalara baktı̆̆ımızda ise durumun sanayileşmiş ülkelerden çok farklı yapıda olduğunu görmekteyiz. Fabrikaya dayalı üretimden uzak Anadolu şehirleri sanayi devriminin getirdiği iktisadi, siyasal ve toplumsal değişimden etkilenmemiştir. 19. yüzyıla kadar zanaat işletmeleri yoluyla üretim yapılmış ve kapalı iktisadi yapı sanayi ürünlerinden etkilenmemiştir. Cumhuriyetin ilanından çok sonra iş kazaları ve meslek hastalıklarına yönelik hukuksal düzenlemeler yapılmaya çalışılmıştır.

\footnotetext{
${ }^{8}$ Arthur H. Estabrook, "The Family History of Robert Owen", Indiana Magazine of History. 19/1, 1923, s.64.

9 A. Gündüz Ökçün, "XIX. Yüzyılın İkinci Yarısında İmalat Sanayi Alanında Verilen Ruhsat ve İmtiyazların Ana Çizgileri", Ankara Üniversitesi Siyasal Bilgiler Fakültesi Dergisi, Cilt: 27, No: 1, Mart 1972, s.s. $160-163$.

${ }^{10}$ B. Umar, İzmir'de Yunanlıların Son Günleri, Bilgi Yayınları Ankara, 1974, s.59. Ayrıca Bakınız: Fahri Sakal, "Türkiye'de Çalışma Hayatının Millileşmesi”, Atatürk Araştırma Merkezi, Cilt.20, Sayı.60, Kasım, 2004.
} 


\section{OSMANLI DEVLETİ DÖNEMINNDE HUKUKSAL DÜZENLEMELER}

Osmanlı Devleti'nde kırsal kesim dışında kalan bölgelerde çalışma hayatı, büyük oranda 19. yüzyılın ortalarına kadar zanaat işletmelerinde sürmüştür. Zanaat işletmeleri fabrika türü işletmeler olmamalarına karşın bölgesel tüketimin tamamını karşılayacak düzeyde üretim yapmışlardır. Ahilik kültürü üzerine şekillenen zanaat işletmelerinde çalışma hayatının kökenleri 13. yüzyıla dayanmaktadır ${ }^{11}$. İşletmelerdeki iş gücü yamak, çırak, kalfa-usta adı verilen hiyerarşi çerçevesinde sürmüş ve her işletme bir okul olmuştur ${ }^{12}$. İşletmeler belli bir loncaya bağlıdır. Yeni iş yerinin açılmasından meslekte yükselmeye kadar birçok yönetimsel işlerden doğrudan lonca sorumludur. Bu yapıları ile günümüz Esnaf ve Sanatkârlar Odalarına, İşçi-İşveren Sendikalarına, benzemektedir ${ }^{13}$. Lonca örgütleri, zanaat işletmelerinin işçi-işveren ilişkisinde birinci derece sorumluluğa sahiptir. Yamak ve çırakların hangi şartlarda çalıştırılacağı, kalfa ve ustalık düzeyine hangi şartlarda yükseleceği örgütün kuralları içinde yer almaktadır ${ }^{14}$.

Bu dönemde zanaat işletmelerinde işçi-işveren ilişkileri, fabrikalardan çok farklı bir yapı sergilemektedir. Ucuz ve bol üretimin her şeyden önemli olduğu sanayi devriminden sonra fabrikalar, işçi emeğini insafsızca sömürmekte, ülkede sosyal politikalar gelişene kadar işçiler, modern köleler halinde çalışmaktadır. Zanaat işletmelerinde ise işçi-işveren veya usta-çırak ilişkisi tamamen baba-oğul ilişkisine benzemektedir. Çocuk yaşta mesleğe giren bireylerin her şeyinden ustası sorumlu olmaktadır. İş yerindeki eğitiminden sağlığına kadar olan sorumluluk, işletmenin dışına da taşmaktadır. Çırağın barınması, evlendiği takdirde düğün masrafları gibi birçok kişisel durumdan usta sorumludur. Öyle ki bu dönemde çırağın veya kalfanın sosyoekonomik sorunlar yaşaması, usta için utanılacak bir durum oluşturmaktadır. Bunun yanında sistem sadece ahlaki değerlerle işlememektedir. Yine aynı dönemde lonca örgütlenmeleri, iktisadi riskleri en aza indirmek amacıyla orta sandığı adı verilen bir sistem oluşturmuştur. Bu sandık birçok riski önlemekle kalmayıp aynı zamanda yeni işletmelere sermaye desteği sağlamıştır ${ }^{15}$. Ahilik felsefesi içinde oluşan işletmelerde çalışma hayatı, 20. yüzyılın ortalarında bile özlemle bahsedilecek bir özeliğe sahip olmuştur ${ }^{16}$.

\footnotetext{
11 Nurettin Öztürk, "Ahilik Teşkilatı ve Günümüz Ekonomisi, Çalışma Hayatı ve İş Ahlakı Açısından Değerlendirilmesi", Dumlupınar Üniversitesi Sosyal Bilimler Dergisi, Sayı: 7, Yıl: 2002, Kütahya, s. 43.

12 Fatih Yücel, Kent Esnaf ve Zanaatkârlarının Ekonomik Sorunları, Tehditler ve Çözüm Önerileri, Yayına Hazırlayan: Kent Araştırmaları Merkezi, Kam Yayınları 1. Baskı, Mayıs 2008, s. 10.

${ }^{13}$ İbrahim Durak, Atilla Yücel, "Ahiliğin Sosyo-Ekonomik Etkileri ve Günümüze Yansımaları", Süleyman Demirel Üniversitesi İktisadi ve İdari Bilimler Fakültesi Dergisi, Yıl: 2010, Cilt: 15, Say1: 2, ss. 164-165.

${ }_{14}$ Ailesinin izniyle çocuklar, zanaat işletmelerine veya mesleğe yamak olarak girilebilirdi. İki yıl ücretsiz çalışan yamak, lonca başkanının bulunduğu törende çıraklığa alınırdı. Bu törenler kalfa ve ustalığa yükselme durumunda tekrarlanırdı.

15 Yücel, a.g.m., s. 153.

161947 yılında TBMM çalışma komisyonu tarafından hazırlanan raporda sanayi işletmelerinde çalışma hayatının olumsuzluklarından bahsedilmiştir. Buna karşın eski zanaat işletmelerinde çalışama hayatındaki olumlu yönlere değinilmiştir: BCA, Yer No: 728.495..5. Fon Kodu: 490..1.0.0 Dosya: 4.BÜRO Sayı : - Tarih: 30.12.1947.
} 
Osmanlı ile sanayileşmiş ülkeler arasında yapılan ticaret anlaşmaları, Avrupalı devletlerin ülkedeki üretim alanlarına nüfuz etmesinin önünü açmış ${ }^{17}$, bu devletlerin fabrikaları için Anadolu toprakları, çok kaliteli hammadde imkânları sağlamıştır. Bundan dolayı yabancı sermaye hammadde üretimi ve bu hammaddenin taşınması üzerine işletmeler kurmayı daha fazla tercih etmiştir ${ }^{18}$. 19. yüzyılın en önemli sanayi hammaddesi ise kömürdür ve Osmanlı topraklarında azımsanmayacak kadar aktif işletilen kömür madeni bulunmaktadır ${ }^{19}$. Ulaşımda ve üretimde kömür kullanımı Osmanlıdaki Ereğli kömür madenlerini daha önemli bir yere getirmiştir. Sultan Mahmut döneminde madenlerin işletilmesi amacıyla "Kömür Madenleri Kumpanyası" adında bir işleme kurulmuştur ${ }^{20}$. 1865 yılında ise madenlerin işletilmesi Bahriye Nezaretine geçmiştir. Yabanc1, yerli ve yakın bölgelerden temin edilen işgücü madenlerdeki zorluğu daha da artırmıştır. Madenlerdeki karmaşık yapıyı ortandan kaldırmak amacıyla Dilaver Paşa göreve gelmiş ve hemen çalışmalara başlamıştır. Bu doğrultuda kendi başkanlığında bir heyet oluşturmuş ve kömür madenlerinin yönetilmesine ilişkin, bir nizamname oluşturmuştur. Komisyon, dört ay içinde, sekiz bölüm yüz madden oluşan “Ereğli Kömür Maden-i Hümayunu Nizamnamesini hazırlamıştır ${ }^{21}$. Günümüzde çalışma hayatına yönelik sosyal politikaların başlangıcı olarak kabul edilen ve Dilaver Paşa Nizamnamesi olarak bilinen kanunun asıl amacı, ocakların daha iyi işletilmesidir. Bununla birlikte kanun maddeleri arasında ocaklarda çalışan ve genellikle amele olarak adlandırılan iş gücünün çalışma koşullarına yönelik düzenlemelere yer verilmesi, nizamnamenin farklı bir yapı kazanmasına neden olmuştur. İşçinin barınmasından çalışma koşulları ve sağlı̆̆ına kadar birçok maddeyi barındıran 1867 tarihli nizamnamenin kanunlaşması hakkında herhangi bir bilgi bulunmamaktadır. Bununla birlikte 1869 Maadin Nizamnamesi, maden işçisini koruyucu tedbirler konusunda daha insancıl bir özelliğe sahip olmuştur.

20. yüzyıl Osmanlı topraklarında fabrika düzeyinde çok fazla işletme bulunmamaktadır22. Avrupa sanayisini besleyen hammadde üretiminse ise hatırı sayılır düzeyde olmuştur. Anadolu'nun gerçek anlamda sanayileşme sürecine girememesi ve devletin çalışma hayatına müdahalesinin yetersiz kalması, işçilerin işverenin inisiyatifine bırakılmasına neden olmuştur. İşçiler, işverene karşı çok farklı eylemlerle seslerini duyurmaya çalışmış ancak devlet işçilerin isteklerini görmezlikten gelmiştir. Osmanlı Devletinde 1869 Maadin Nizamnamesi dışında iş kazaları ve meslek hastalıklarına yönelik hukuksal düzenlemelere rastlanmamaktadır.

\footnotetext{
17 Yusuf Kemal Tengirşenk, "Tanzimat Devrinde Osmanlı Devletinin Haricî Siyaseti", Komisyon, Tanzimat 1, İstanbul: MEB Yayınları, 1999, ss. 298-299.

1823 Eylül 1856 yılında ilk demiryolu İzmir- Aydın hatıının bir İngiliz firması tarafından yaptırılmıştır.

${ }^{19}$ Fahrettin Tızlak, Osmanlı Döneminde Keban-Ergani Yöresinde Madencilik, TTK Yayınları, Ankara, 1997, s.4-5.

${ }^{20}$ Hamdi Genç, Ereğli Kömür Madenleri, (1840-1920), Basılmamış Doktora Tezi, Marmara Üniversitesi Sosyal Bilimler Enstitüsü, İstanbul, 2007, s.32.

${ }^{21}$ Cevat Ülkekul, Taş Kömürü Havzasında (İşletmelerinde) Bahriye Nezareti Yönetimi (1865-1908) ve Dilaver Paşa Nizamnamesi, Çeviriler: Ayşe Hande Çan, s.62,63.

22 Sayımlarına göre işletmelerinin çoğu değirmenlerden oluşmaktadır. Tevfik Güran, “1897 Tarihli İlk İstatistik Yıllı̆̆ı", Osmanlı Devleti'nde Bilgi ve İstatistik, D.İ.E. Yayınları, Ankara, 2000, s.169,170.
} 


\section{CUMHURIYETIN İLK YILLARI}

Milli Mücadelenin ardından en önemli sorunlardan biri de Osmanlı Devleti'nin son yarım yüzyılında başlatılan sanayileşme çalışmalarının nasıl sürdürüleceğidir. Gerçek anlamda bağımsızlığın, sanayileşme ile olacağı, dönemin aydınlarının ortak düşüncesidir. Bu doğrultuda 1923 yılında İzmir'de iktisat kongresi düzenlenmiştir. Kongreye üretimde aktif rol oynayan grupların katılımı ve onların görüşleri, ileriki yıllar için ümit verici olmuştur. Bu kongrede yerli sermaye ile fabrikalar kurulması ilk hedeftir. Yerli sanayinin gelişmesine yönelik imtiyazlar ve teşvikler, bu dönemdeki iktisat politikalarının özünü oluşturmuştur. Anadolu'nun farklı bölgelerine fabrika kurma düşüncesi, Türk işçisinin sorunlarının gündeme gelmesini engellemiştir. İşçilerin sosyoekonomik hakları 30'lu yıllara kadar işverenin inisiyatifine bırakılmıştır.

\subsection{Umumi Hifzıssıhha Kanunu}

Demokrasinin gelişmesi, hükümetlerin sosyoekonomik yapıya daha fazla müdahale etmesi gerekliliğini ortaya çıarmıştır. Günümüz demokrasi unsurları arasında sosyal devlet anlayışı, halkın menfaatleri doğrultusunda hükümetlerin, eğitimden sağlığa birçok alanda doğrudan müdahalesini kapsamakta, bununla birlikte 1930 yılında yürürlüğe giren Umumi Hıfzıssıhha Kanunu, demokrasinin yavaş yavaş geliştiği Türkiye' de halkın sağlığını korumak amaçlı devlet müdahalesini içermektedir. Savaşlar, göçler, sağlık imkânlarının yetersizliği Cumhuriyetin ilk yıllarında böyle bir kanunun çıkmasını zorunlu kılmıştır. Ayrıca devletçilik uygulamalarının yavaş yavaş hükümet politikası halini aldığı 30'lu yılların başlarında, iş̧̧ilerin sağlığı devlet için daha fazla önem teşkil etmeye başlamıştır. Koruma önlemlerin bütün kesimleri kapsayacak bir şekilde devlet yükümlülükleri içerisine alınmıştır ${ }^{23}$ :

"Madde 1: Memleketin sthhi şartların ıslah ve milletin sthhatine zarar veren bütün hastalıklar veya sair muzır amillerle mücadele etmek ve müstakbel neslin sihhatli olarak yetişmesini temin ve halkı tıbbi ve içtimai muavenete mazhar eylemek umumi devlet hizmetlerindendir.

Madde 2: Umumi sihhat ve içtimai muavenet hizmetine ait devlet vazife Sihhat ve İçtimai Muavenet Vekaleti tarafindan ifa ve hususi idarelerle belediyelere sureti icrası murakabe olunur. Milli müdafaa teşkilatına ait sıhhi işler müstesna olmak üzere bütün sihhat ve içtimai muavenet işlerinin merci ve murakıbı belediyelerdir."

Kanunun ilk iki maddesinden de anlaşılacağı üzere kapsamı, olabildiğince geniş tutulmuştur. Madenler dışında işçi sağlığı ve güvenliğinin ilk defa hukuksal boyutta ele alınması sosyal politikaların gelişmesi açısından önemlidir. İş Kanununa kadar işçilerin sağlığı Umumi Hıfzıssıhha Kanununu kapsaminda korunmaya çalışılmıştır. Kanunun işçilerin sağlığına yönelik maddeleri, altıncı ve yedinci bölümlerde, "işçiler hıfzıssıhhası" başlığı altında toplanmıştır. Bu başlık altında kadın ve çocuk işçiler öncelikli korunması gereken kesim olarak kabul edilmiştir. Sanayi

\footnotetext{
23 TBMM Kavanin Mecmuası, Devre:3 İcdima: 3, Cilt.8, TBMM Matbaası, Ankara, 1930, s. 201, Resmi Gazete 6.5.1930, Sayı: 1489.
} 
işletmelerinde ucuz işgücü olarak kabul edilen kadın ve çocuk emeği, devletin kontrolüne geçmiştir.

İşçi sağlığı ve güvenliği kanununun sosyal politikaların gelişiminde etkisi büyüktür. Bu doğrultuda;

- 12 yaşının altında çocukların çalıştırılması yasaklanmıştır,

- 12 ile 16 yaş arası çocukların çalışma saatlerine sınırlama getirilmiştir,

- 18 yaşının altındaki bireylerin çalışma alanları sınırlandırılmıştır,

- Hamile kadınların çalışma koşulları ve çalışma saatleri yeniden düzenlenmiştir,

- Tehlikeli ve ağır işte çalışacak işçilerin sağlığının korunması için düzenlemeler yapilmıştır,

- İşletmelerde işçilerin iyi şekilde barınması ve beslenmesine yönelik tedbirler alınmıştır,

- İşçilerin sağlık kontrolünden geçmesi için işletmelerin doktor bulundurulması zorunluluğu getirilmiştir.

\subsubsection{Sayılı İş Kanunu}

1936 tarihine kadar Türkiye'de çalışma hayatını doğrudan etkilen çok az kanunun bulunmaktadır. Kanunların bazısı, doğrudan çalışma hayatını etkilerken, bazıları ise dolaylı yönden etkilemiştir. Anadolu'nun yüz yıllı aşkın sanayileşme sürecinde yönetici kadroların iş kanunu yapmak için fazla bir çaba harcamaması, bu şekilde dağınık bir durumun oluşmasına neden olmuştur ${ }^{24}$. Bu dağınık yapıyı, ortadan kaldırma çalışmaları, 1924 yılında başlamış ve ancak 1936 yılında sonuçlanarak ${ }^{25}$ aynı yıl kanunlaşıp 1937 yılında yürürlüğe girmiştir ${ }^{26}$. Kanun çalışma hayatını düzenlemeye yönelik doğrudan ve genel birçok maddeyi barındırmaktadır. Ayrıca işçi, işveren ve devlet, çalışma hayatının hukuksal boyutta tarafları olarak kabul edilmiştir. İşçilerin iş sağ lığı ve meslek hastalığ1 "İşçilerin sağlığını koruma ve iş emniyeti" başlığı altında düzenlenmiş ve Umumi hıfzıssıhha kanununun işçi sağlı̆̆ı konusunda yer alan maddelere atıf yapılarak uygulanması hedeflenmiştir. İlk defa işçi sağlığı konusunda işverenin tam sorumlu tutulması, Sosyal Politikaların temeli olan işçi-işveren- devlet üçlemesinin oluşması için önemlidir.

Kanunun 54. maddesinde yer alan "Her işveren, işyerinde işçilerin sağliğıı koruma ve iş emniyetini temin etmek için gerekli olan tedbirleri almakla ve bu husustaki şartları ve tertibatı noksansız bulundurmakla mükelleftir." cümlesi, bütün iş kazası ve meslek hastalığından işvereni sınırsız sorumlu hale getirmiştir. İş yerindeki gereken tedbirlerin alınıp alınmadığına dair denetleme tamamen devletin sorumluluğu altına alınmıştır. İş Kanunu ile Umumi Hıfzıssıhha Kanunu iş güvenliği ve meslek hastalığı konusunda benzer konular üzerinde durulmuştur. Kanunda sosyal yardımlar başlığ 1 altında iş kazası, meslek hastalığı, analık, ihtiyarlık, işten kalma, hastalık ve ölüm

\footnotetext{
${ }^{24}$ Talas, a.g.e, s. 137.

${ }^{25}$ Mesut Gülmez, Türkiye'de Çalışma İlişkileri (1936 Öncesi), Türkiye ve Ortadoğu Amme İdaresi Enstitüsü Yayınları, Ankara, 1983, s.204,205

${ }^{26}$ Resmi Gazete 15.06.1936, Say1:3330.
} 
hallerinde yapılacak yardımlar, devlet tarafından karşılanması öngörülmüştür. Bu doğrultuda bir yıl sonra iş sigortası kurumu kurulması kararlaştırılmıştır.

İşçilere yapılacak sosyal yardımlar, devlete bütçesine büyük bir külfet getirmektedir. Sosyal sigortaların finansmanını sağlamak, dönemin Türkiye'si için oldukça zor bir durum olmuştur. II. Dünya savaşının başlaması, 1937 yılında kurulması planlanan sigortalar kurumunun ancak sekiz sene sonra kurulmasina olanak sağlamıştır.

\section{3. İş Kazalarıyla Meslek Hastalıkları ve Analık Sigortaları Kanunu ile İşçi Sigortaları Kurumu Kanunu}

Sanayi teşvik kanunları ve Birinci Beş Yıllık Sanayi Planı çerçevesinde, ülkenin koşularına uygun kurulan işletmeler, sanayide çalışan işçi sayısının artmasında önemli katkı sağlamıştır. Sanayide istihdam edilen işçi sayısı artıkça çalışma hayatına yönelik sosyal politikalarda gelişmiştir. Bununla birlikte iş kanunu uygulanışında sorunlar yaşanmıştır. İş kanunun ikinci maddesi tam anlamıyla Türkiye'de işçileri ikiye bölmüştür. Kanunun ikinci maddesi $\mathrm{A}$ bendi27:

"Bu kanun, mahiyeti itibarı ile yolunda işleyebilmesi için günde en az on işçi çalıştırmă̆̆
icap ettiren işyerlerine ve buralarda çalışan işçilerle bunların işverenlerine tatbik olunur. İ̧̧
Kanununun tatbikatını temin ve takibe salâhiyettar makam tarafından bu hükü̈m
mucibince tasnif edilmiş olmak vaziyetine karşı işveren veya işçisi tarafından vuku bulacak
itirazlar İktisat Vekâletince incelenerek kesin bir karara bağlanır."

Dönemin şartları göz önüne alındığında Türkiye'de on ve üzeri işçi çalıştıran işletme sayısı çok fazla değildir. Kanuna böyle bir maddenin konulması, birçok işçiyi işverenin inisiyatifine bırakmak anlamı taşımaktadır. Çalışama hayatına yönelik kanunların genel bir yapıya sahip olmama sorunlarından bir diğeri ise grevin kesin bir dille yasaklanmasıdır. Böylece işçinin işverene karşı tek yaptırım gücü engellenmiştir. Diğer bir sorun da iş sigortaları ile ilgili kurumların ve alt yapının oluşturulamamasıdır. Bu dönemde işletme sahipleri, türlü türlü yöntemlerle iş kanunu kapsamından çıkmak için çalışmaktadır. İşverenin en çok kullandığı yöntem ise; işletmeleri bölerek çalışanları on kişinin altında göstererek iş kanunu kapsamı dışına çıkmaktır ${ }^{28}$. İşletmelerin çalışma koşullarını gerçek anlamda denetleyecek bir kurumun olmaması, işçiler için olumsuz koşullar anlamı taşımaktadır.

II. Dünya Savaşı, Türkiye'de işçi kesimi için son derece yıpratıcı bir dönem oluşturmuştur. İşçiyi koruyucu önlemlerin son derece yetersiz ve çalışma koşulları olabildiğince ağırdır. Bunun yanında temel gıda maddelerinin fiyatlarının artması ve çoğunlukla ücretlerinin sabit kalması nedeniyle bu dönem emeği ile kazananalar için birçok sorunun yaşandığı bir dönem olmuştur. Devlet işçiyi birçok alanda korumaya çalışmış, ancak fazla başarılı olamamıştır. II. Dünya Savaşının bitimi ile birlikte özelikle

\footnotetext{
${ }^{27}$ A.g.g.

28 İşveren işletmeyi kısım kısım bölerek, bölünerek küçük işletme gibi göstermesi 1947 tarihli meclis araştırma raporlarına yansımıştır. BCA, Yer No: 728.495..5. Fon Kodu: 490..1.0.0 Dosya: 4.BÜRO Sayı : Tarih: 30.12.1947.
} 
savaştan önce başlamış olan ama yarım kalan işçiyi koruyucu tedbirlerin alınmasına yönelik tedbirlere hız verilmiştir. 1945 yılında ilk önce İş Kazalarıyla Meslek Hastalıkları ve Analık Sigortaları Kanunu ${ }^{29}$ daha sonra da İşçi Sigortaları Kurumu $K$ anunu $^{30}$ yürürlüğe girmiştir. Hükümet tarafından çalışma hayatına yönelik sosyal politikalara, devam edilmeye çalışılmıştır. Özellikle iş kazaları, meslek hastalıkları ve analık sigortası sanayileşmiş ülkelerin 19. yüzyılın ortalarından itibaren gerçekleştirdikleri koruyucu önlemler, Türkiye'de ancak 20. yüzyılın ortalarında oluşmuştur.

İş Kazalarıyla Meslek Hastalıkları ve Analık Sigortası Kanunu, bir başlangıcı temsil etmektedir. Kanun 3008 sayılı iş kanunu kapsamında çalışan işçileri kapsamaktadır. İş kazası günümüzde de kullanılan tanıma, bu kanunla kavuşmuştur. Kanunda hem meslek hastalığı hem de analık tanımı yapılmış, yapısal olarak ilkleri barındırmıştır. İş sigortalarının finansmanın sadece işveren tarafından karşılanması öngörülmüştür. Kanuna göre iş kazaları:

İş kazası, sigortalının aşağıdaki hal ve durumlardan birinde vuku bulan ve sigortalıyı hemen veya sonradan bedence veya ruhça arızaya uğratan olaydır:

- Sigortalının işyerinde bulunduğu sırada,

- İşveren veya vekili tarafından yürütülmekte olan iş dolayısıyla,

- Sigortalının işyerinde can kurtarmak için veya işverenin, yahut işyerinin veya yürütülen İşin çıkarma ve faydasına çalıştığı sırada,

- 3008 sayılı İş Kanununun 40. maddesine göre günlük iş süresi içinde sayılması gereken zamanlarda

Bununla birlikte özellikle kaza veya meslek hastalığı durumunda; geçici iş görmemezlik, daimi kısmı iş görmemezlik, daimi tam iş göremezlik ve ölüm durumlarında analıkta ise; sigortalının ana olması veya sigortalının karısının ana olması kanun kapsamı içine alınmıştır. İş kazalarıyla meslek hastalıkları ve analık sigortası kanunu ile İşçi Sigortaları Kurumu Kanunu ile çalışma hayatına yönelik hukuksal düzenlemelerdeki büyük bir eksiklik giderilmiştir.

\section{SONUÇ}

Cumhuriyetin ilanından sonra Türk toplumu, inkılaplar sayesinde büyük değişimler yaşamıştır. Değişimin bazı alanlarda çok hızlı olmasına karşılık, iktisadi alanlarda yaşanması daha uzun bir süre almıştır. Osmanlı Devleti'nin son dönemlerinde başlayan sanayileşme süreci yeni Türkiye'nin ilk on yılında fazla ilerleme sağlanamamıştır. Sanayi toplumu oluşturma yönündeki çalışmalar, birçok sorun nedeniyle çok yavaş ilerlemektedir. Üretim unsurlarını, yerli ve yabancı özel sermayeye verilen imtiyazlarla artırmaya çalışan devleti yöneten kadrolar, fazla başarı sağlayamamıştır. Cumhuriyetin ilk yıllarında sanayileşmeyi en büyük hedeflerden biri görülmüş, işçi hakları konusunda neredeyse hiçbir hukuksal düzenlemeye gidilmemiştir. Sanayileşme sürecinde işçi güvenliği ve meslek hastalıkları öncelikli

\footnotetext{
${ }^{29}$ Resmi Gazete 7.7.1945, Sayı: 6051.

${ }^{30}$ Resmi Gazete 16.7.1945, Sayı: 6058.
} 
konular arasında yer alamamıştır. Özellikle işçi sigortaları işveren için oldukça maliyetli bir konudur ve bu dönemde öncelikler arasında olmamıştır.

Büyük buhran ve cari açık, ülkede farklı iktisat politikalarını zorunlu kılmıştır. 20. yüzyılın başlarından itibaren özel sermayeye verilen teşvikler, fabrika türü üretimin oluşması için yeterli olmamıştır. 30'lu yılların başında iktisadi nedenlerden dolayı temel gıda maddelerinin fiyatları artmış ve bulunması zorlaşmıştır. Bu sorunlar özel sektörü destekleme politikalarının yanında devletin iktisadi hayata işletmeci olarak girmesine neden olmuştur. Anadolu'nun değişik bölgelerine açlan fabrikalar, devleti en büyük işveren haline getirmiştir. Büyük buhrandan sadece 6-7 yıl sonra ülke cari fazla vermiştir.

Türkiye'de devletin en büyük işveren haline gelmesi, çalışma hayatına yönelik sosyal politikaların değişmesine yol açmıştır. Temel iş güvenliği önlemleri, önce genel daha sonra da iş kanunu kapsamında artırılmıştır. İş kazaları ve meslek hastalıklarının hem önlenmesi hem de oluşması durumunda iş̧̧iye yapılacak yardımların finansmanı konusunda düzenlemeler genel olarak iş kanunu kapsamına alınmıştır. 1930 tarihinde ilk önce Umumi Hıfzımsa kanunu kapsamında işçinin sağlı̆̆ından ve güvenliğinden tamamen işveren sorumlu kılınmıştır. Türkiye' de ilk defa işçilerin sağlığg ve güvenliği genel bir kanunla korunmaya çalışılmıştır. İş kazaları ve meslek hastalıkları konusunda konusun da gerçek anlamda yasal düzenleme, 3008 Sayılı İş Kanunu ile olmuştur. Bu kapsamda ayrıca yine ilk defa işverenin ödediği primlerle bir iş sigortası sistemi kurulmuştur.

Hem Umumu Hıfzıssıhha Kanunu hem de iş kanunu, iş sağlığı ve hastalıkları konusunda olumlu olmasına karşılık birçok eksik yönü bulunmaktadır. İlk önce Umumi Hıfzıssıhha Kanununa baktığımızda; iş sağlığı ve güvenliği konusunda yerel yönetimlerine yetki verilmektedir. Denetlemenin yerel yönetimde olmasına karşıllı, koruyucu tedbirlerin ne olacağı tam olarak belirlenmemiştir. Gelişen sanayi sektöründe işçi güvenliği ve sağlığı uzmanlık gerektiren bir yapıdadır. Bu dönemde tam olarak hangi işletmenin hangi tedbiri alacağ 1 kesin değildir. İş Kanununda ise sorunlar daha karmaşık bir yapı oluşturmuştur. Kanunun ikinci maddesinde yer alan on kişi ve üstü işletmelerde uygulanır ibaresi, birçok işçiyi kapsam dışında bırakmıştır. Bununla birlikte iş kazası, meslek hastalığı ve analık sigortalarının finansmanı için gerekli olan kanun yaklaşık sekiz sene sonra yürürlüğe girmiştir. Pirim sistemi ise sadece işverenin yükü olarak kabul edilmiştir. İşveren tarafından finansa edilen sistemin, ne kadar uygulanabilir olduğu tartışmalıdır.

İş kazaları ve meslek hastalıklarının konusunda hukuksal düzenlemeler sanayileşme süreci ve II. Dünya Savaşının yarattığı sıkıntılar nedeniyle geç ve eksik başlamıştır. İşçi sağlığı ve hastalığının önlenmesine yönelik düzenlemeler, işveren için önemli bir maliyet oluşturmaktadır. Devleti yöneten kadroların bu konuda yeterli hukuksal düzenlemeler yapmaması, aslında işverenin işine gelmiştir. Birçok işletme değişik yöntemlerle yükümlülüklerden kurtulmaya çalışmıştır. 


\section{KAYNAKÇA}

Aydemir, M. (1994). "İşçi Sağlığı ve İş Güvenliğini Sağlama Açısından İşverenin Yükümlüğü”, Kamu-İş İş Hukuku ve İktisat Dergisi, Cilt.3, Sayı.4.

BCA Yer No: 728.495..5. Fon Kodu: 490..1.0.0 Dosya: 4.BÜRO Say1 : - Tarih: 30.12.1947.

Durak, İ. ve Atilla, Y. (2010). "Ahiliğin Sosyo-Ekonomik Etkileri ve Günümüze Yansımaları", Süleyman Demirel Üniversitesi İktisadi ve İdari Bilimler Fakültesi Dergisi, Cilt: 15, Sayı: 2 .

Estabrook, A. H. (1923). "The Family History of Robert Owen", Indiana Magazine of History. $19 / 1$.

Genç, H. (2007). Ereğli Kömür Madenleri, (1840-1920), Basılmamış Doktora Tezi, Marmara Üniversitesi Sosyal Bilimler Enstitüsü, İstanbul.

Gülmez, M. (1983). Türkiye'de Çalışma İlişkileri (1936 Öncesi), Türkiye ve Ortadoğu Amme İdaresi Enstitüsü Yayınları, Ankara.

Güran, T. (2000). "1897 Tarihli İlk İstatistik Yıllığı”, Osmanlı Devleti'nde Bilgi ve İstatistik, D.İ.E. Yayınları, Ankara.

Hobsbawn, E. J. (1998). Sanayi ve İmparatorluk, Çeviren: Abdullah Ersoy, Dost Yayınları, Ankara.

Kennedy, P. (1994) Büyük Güçlerin Yükseliş ve Çöküşleri, Çeviren: Birtane Karanakçı, Türkiye İş Bankası Yayınları, Ankara.

Ökçün, A. G. (1972). "XIX. Yüzyılın İkinci Yarısında İmalat Sanayi Alanında Verilen Ruhsat ve İmtiyazların Ana Çizgileri", AÜSBFD, Cilt: 27, No: 1.

Öztürk, N. (2002). "Ahilik Teşkilatı ve Günümüz Ekonomisi, Çalışma Hayatı ve İş Ahlakı Açısından Değerlendirilmesi", Dumlupınar Üniversitesi Sosyal Bilimler Dergisi, Sayı: 7.

Resmi Gazete

Sakal, F. (2004). “Türkiye'de Çalışma Hayatının Millileşmesi”, Atatürk Araştırma Merkezi, Cilt.20, Sayı.60.

Talas, C. (1955). İçtimai İktisat Dersleri, Ankara Üniversitesi Siyasal Bilgiler Fakültesi Yayınları, Ankara.

TBMM Kavanin Mecmuası, Devre:3 İcdima: 3, Cilt.8, TBMM Matbaası, Ankara, 1930.

Tengirşenk, Y. K. (1999). "Tanzimat Devrinde Osmanlı Devletinin Haricî Siyaseti", Komisyon, Tanzimat 1, İstanbul: MEB Yayınları.

Tızlak, F. (1997). Osmanlı Döneminde Keban-Ergani Yöresinde Madencilik, TTK Yayınları, Ankara.

Tuna Orhan, Nevzat Yalçıntaş, Sosyal Siyaset, Filiz Yayınları, İstanbul, 1988.

Turan, Y. Z. ve Çolak, R. (2016). “Bildungsroman'a Tematik Bir Yaklaşım: David Copperfield ve Çalıkuşu". Humanitas: Uluslararası Sosyal Bilimler Dergisi, Cilt.4, Sayı.7.

Umar, B. (1974). İzmir' de Yunanlıların Son Günleri, Bilgi Yayınları Ankara.

Ülkekul, C. Taş Kömürü Havzasında (İşletmelerinde) Bahriye Nezareti Yönetimi (1865-1908) ve Dilaver Paşa Nizamnamesi, Çeviriler: Ayşe Hande Çan. 
Ö. Deniz / Karabük Üniversitesi Sosyal Bilimler Enstitüsï Dergisi, 2018, 8 (2), 258-269

Yücel, F. (2008). Kent Esnaf ve Zanaatkarlarının Ekonomik Sorunları, Tehditler ve Çözüm Önerileri, Yayına Hazırlayan: Kent Araştırmaları Merkezi, Kam Yayınları 1. Baskı. 